\title{
ANALISIS PENGAMBILAN KEPUTUSAN DALAM TRANSAKSI TRADING FOREX DI FXINDO REGIONAL LAMONGAN
}

\author{
*)Titin \\ Fakultas Ekonomi \\ Universitas Lamongan
}

\begin{abstract}
ABSTRAK
Foreign Exchange, lebih dikenal dengan istilah forex, merupakan salah satu pilihan investasi yang berkembang di Indonesia. Forex Trading adalah transaksi perdagangan nilai tukar mata uang asing di pasar uang internasional, sering kali para trader mengalami kesulitan untuk menentukan harga di masa mendatang, untuk itu perlu adanya sebuah analisis yang tepat untuk mengambil keputusan. Sebelum mengambil keputusa dibutuhkan suatu analisis yaitu analisis Fundamental dan Teknikal. Oleh karna itu penelitih melakukan penelitihan di FXindo Regional Lamongan untuk mempermudah pengambilan keputusan dalam transaksi Tradin Forex. Penelitian ini dilakukan untuk mengetahui faktor faktor (Fundamental dan Teknikal) berpengaruh secara parsial, simultan dan Variabel bebas yang perpengaruh paling dominan terhadap pengambilan keputusa dalam transaksi Trading Forex FXindo Regional Lamongan, data diperoleh menggunakan penyebaran angket yang diisi 30 responden oleh para trader di FXindo Regional Lamongan, dari data tersebut hasil Hipotesis yang diperoleh Secara Parsial Analisis Fundamental $\left(X_{1}\right)$ berpengaruh secara signifikan terhadap pengambilan keputusan ( $Y$ ) karena mampunyai nilai $t_{\text {hitung }}$ yang lebih besar dibandingkan dengan nilai $t_{\text {tabel }}$ yaitu 5,345 > 2,052. Sedangakan Analisis Teknikal $\left(\mathrm{X}_{2}\right)$ juga berpengaruh signifikan terhadap pengambilan keputusan $(Y)$ karena nilai $t_{\text {hitung }}$ lebih besar dibandingkan dengan nilai $t_{\text {tabel }}$ yaitu 3,488 > 2,052. Secara simultan variabel bebas Analisis Fundamental $\left(X_{1}\right)$ dan Analisis Teknikal $\left(X_{2}\right)$ berpengaruh secara signifikan terhadap pengambilan keputusan $(Y)$. Hal ini dibuktikan dengan besarnya nilai $F$ hitung dibandingkan dengan nilai $F$ tabel yaitu 19,638>3,3541. Kesimpulan yang diperoleh Variabel bebas Analisis Fundamental $\left(X_{1}\right)$ dan Analisis Teknikal $\left(X_{2}\right)$ keduanya berpengaruh secara signifikan terhadap pengambilan keputusan $(Y)$, karena mampunyai nilai thitung yang lebih besar dibandingkan dengan nilai $t_{\text {tabel }}$, dari kedua Variabel tersebut Variabel Analisis Fundamental $\left(X_{1}\right)$ berpengaruh paling dominan terhadap pengambilan keputusan (Y). secara menyeluruh dan bentuk tolak pada permasalahan yang di hadapi, maka saran yang dapat di berikan yaitu Diharapkan para trader forex harus berhati-hati dalam pengambilan keputusan dan untuk melakukan trading forex sangat diperlukan analisis fundamental atau teknikal sehingga resiko kerugian yang ditimbulkan dapat di minimalisir.
\end{abstract}

Kata Kunci : Fundamental, Tehnikal, Trading Forex

\section{PENDAHULUAN}

Foreign Exchange, lebih dikenal dengan istilah forex, merupakan salah satu pilihan investasi yang berkembang di Indonesia. Forex Trading adalah transaksi perdagangan nilai tukar mata uang asing di pasar uang internasional. Forex berbeda dengan money changer. Pada money changer, jual beli dilakukan secara fisik (memiliki tempat dan barang), transaksi forex dilakukan 
dengan memindahbukukan dana pada rekening bank antara trader.

Pasar forex sebenarnya adalah pasar uang terbesar di dunia. Banyak sekali trader yang terlibat di dalamnya, perusahaan bertaraf internasional, bankbank dunia maupun individu. Banyaknya trader di pasar ini membuat perputaran uang menjadi sangat cepat.

Perputaran uang yang begitu cepat, selain diakibatkan oleh banyaknya jumlah trader, juga dipengaruhi oleh berbagai macam faktor, seperti faktor ekonomi, politik dan sosial suatu negara. Akibatnya, harga menjadi sangat fluktuatif. Harga yang sangat fluktuatif merupakan resiko yang harus dihadapi para trader.

.Harga suatu mata uang terhadap mata uang lain akan mengalami peningkatan (bullish) ataupun penurunan (bearish). Jika harga suatu mata uang mengalami bullish terhadap mata uang lain, maka perdagangan forex diawali dengan open-buy dan akan diakhiri dengan close-sell. Selisih antara harga beli dan harga jual adalah keuntungan yang diperoleh trader. Sumber (www.repository.usu.ac.id).

Transaksi Forex (Foreign Exchange Trading) merupakan suatu bentuk perdagangan mata uang yang melibatkan pasar uang utama dunia. Mata uang yang diperdagangkan setiap jam atas dasar global dan kursnya beruba hampir secara terus menerus. Karena banyak transaksi ekonomi yang berhubungan degan transfer satu mata uang lainnya di masa mendatang. Ketidakstabilan nilai tukar mendorong sejumlah ketidak pastian substansial dari transaksi-transaksi tersebut.

Perdagangan mata uang asing (forex) dalam perdagangan berjangka adalah perdagangan yang transaksinya dilakukan melalui kontrak beli dan atau kontrak jual dari mata uang asing yang di perdagangkan di bursa. Pengambilan keputusan dalam transaksi tersebut dapat menentukan potential profit (keuntungan) maupun potential loss (kerugian) yang akan dialami ketika mengambil posisi buy(membeli) ataupun sell (menjual).

Dalam semua bidang investasi, kemungkinan terjadinya risiko kerugian yang tidak diharapkan dalam pengambilan keputusan tersebut bisa saja terjadi. Karena pada dasarnya tidak ada satupun investasi yang sepenuhnya terbebas dari risiko.

Pelaku-pelaku ekonomi sangat dipengaruhi oleh ketidakpastian nilai tukar masa mendatang. Barang-barang yang diimpor harus dibayar pada masa yang akan datang, eskportir berharap menerima pembayaran dalam mata uang asing, pinjaman-pinjaman yang jatuh tempo untuk dibayarkan kembali di tahun-tahun yang akan datang.

Risiko kegagalan ada dalam setiap keputusan, dengan adanya ketidak pastian akan pergerakan harga yang terjadi, resiko pengambilan keputusan yang ada dalam setiap pertumbuhan ekonomi dan perubahan aspek lain yang terjadi sangatlah cepat.

Oleh karena itu sebelum keputusan diambil dibutuhkan suatu analisis yang tepat. Faktor analisis yang dikenal untuk meminimalisasi risiko kerugian dalam pengambilan keputusan dalam transaksi forex ada dua macam, yaitu Analisis Fundamental dan Analisis Teknikal. Sumber (King,http://www.fxindo.com): "Risiko ada di setiap investasi, tetapi sekali lagi, forex berada dalam kelas tersendiri. 
Bahkan ketika Anda tetap menerapkan leverage yang wajar, trading Anda tetap selalu disertai risiko."

Analisis fundamental adalah metode analisis yang memperhatikan permintaan dan penawaran pasar suatu Negara yang akan mempengaruhi harga pasar. Sedangkan analisis teknikal adalah suatu metode analisis yang mencari pola pergerakan harga, sehingga pola pergerakan harga di masa yang akan datang akan dapat diprediksi.

Kedua analisis dalam transaksi forex dapat mempengaruhi seorang trader untuk mengambil keputusan di perdagangan berjangka. Sehingga sangat penting untuk mengetahui faktor-faktor analisis apa saja yang dapat mempengaruhi pengambilan keputusan dalam transaksi forex di perdagangan berjangka, Berdasarkan latar belakang permasalahan tersebut di atas, maka penulis mengambil judul penelitian :

"Analisis yang Berpengaruh Terhadap Pengambilan Keputusan dalam Transaksi Trading Forex Pada FXindo Regional Lamongan"

\section{METODE PENELITIAN}

Dalam penyusunan skripsi ini penulis melakukan penelitian pada awal bulan Januari sampai Mei tahun 2014 pada FXindo Regional Lamongan.

Lokasi Penelitihan ini merupakan tempat dimana peneliti melakukan penelitihan untuk memperoleh datadata yang diperlukan. Adapun penelitihan ini di laksanakan di "FXindo Regional Lamongan" Kabupaten Lamongan.

Dalam penelitian ini dideskripsikan atau digambarkan secara obyektif realita sebenarnya sesuai dengan fenomena yang ada di Kabupaten Lamongan tentang pengaruhanalisis Trading Forex "FXindo Regional Lamongan". Pendekatan penelitian yang digunakan adalah pendekatan kuantitatif yaitu pendekatan dengan menggunakan angka-angka, mulai dari pengumpulan data, penafsiran terhadap data tersebut, serta penampilan dari hasilnya. (Suharsimi arikunto, 2010;27)

Dengan cara penarikan sempel Populasidiartikan sebagai keseluruan subyek penelitian. Apabila seseorang ingin meneliti semua elemen yang ada dalam wilayah penelitian, maka penelitiannya merupakan penelitian populasi (Suharsimi arikunto, 2010;173).Yang mana dalam penelitian ini populasi yang akan digunakan adalah para Trader di "FXindo Regional Lamongan" di Kabupaten Lamongan, yang berjumlah 30 responden.

Menurut (Suharsimi arikunto, 2010;174), sampel adalah sebagian dari populasi, Maksutnya jika kita hanya meneliti sebagian kecil dari populasi, maka penelitianya dinamakan sampel.

Apabila subyek penelitian kurang dari 100, lebih baik diambil semua, tetapi jika subyeknya besar atau lebih dari 100 maka dapat diambil antara 10$15 \%$ atau $20-25 \%$ atau lebih. Secara umum semakin besar sample maka semakin representative. Dalam pemilihan sampel yang mewakili populasi tersebut, teknik yang digunakan adalah sampling, merupakan teknik pengambilan sampling yang digunakan untuk memilih sampel berdasarkan kriteria bahwa responden yang dipilih adalah Trader " FXindo Regional Lamongan" di Kabupaten Lamongan. 
Dalam penelitian ini besarnya sampel yang diambil adalah sebanyak 30 responden, karena objek penelitian ini kurang dari 100 orang, maka oleh peneliti diambil semuanya.

\section{PEMBAHASAN}

Foreign Exchange, lebih dikenal dengan istilah forex, merupakan salah satu pilihan investasi yang berkembang di Indonesia. Forex Trading adalah transaksi perdagangan nilai tukar mata uang asing di pasar uang internasional, sering kali para trader mengalami kesulitan untuk menentukan harga di masa mendatang, untuk itu perlu adanya sebuah analisis yang tepat untuk mengambil keputusan. Sebelum mengambil keputusa dibutuhkan suatu analisis yaitu analisis Fundamental dan Teknikal. Oleh karna itu penelitih melakukan penelitihan di FXindo Regional Lamongan untuk mempermudah pengambilan keputusan dalam transaksi Tradin Forex.

Penelitian ini dilakukan untuk mengetahui faktor faktor (Fundamental dan Teknikal) berpengaruh secara parsial, simultan dan Variabel bebas yang perpengaruh paling dominan terhadap pengambilan keputusa dalam transaksi Trading Forex FXindo Regional Lamongan, data diperoleh menggunakan penyebaran angket yang diisi 30 responden oleh para trader di FXindo Regional Lamongan, dari data tersebut hasil Hipotesis yang diperoleh Secara Parsial Analisis Fundamental $\left(\mathrm{X}_{1}\right)$ berpengaruh secara signifikan terhadap pengambilan keputusan (Y) karena mampunyai nilai $t_{\text {hitung yang lebih besar dibandingkan }}$ dengan nilai $t_{\text {tabel }}$ yaitu $5,345>2,052$. Sedangakan Analisis Teknikal $\left(\mathrm{X}_{2}\right)$ juga berpengaruh signifikan terhadap pengambilan keputusan (Y) karena nilai $\mathrm{t}_{\text {hitung }}$ lebih besar dibandingkan dengan nilai $t_{\text {tabel }}$ yaitu $3,488>2,052$. Secara simultan variabel bebas Analisis Fundamental $\left(\mathrm{X}_{1}\right)$ dan Analisis Teknikal $\left(\mathrm{X}_{2}\right)$ berpengaruh secara signifikan terhadap pengambilan keputusan (Y). Hal ini dibuktikan dengan besarnya nilai $\mathrm{F}_{\text {hitung }}$ dibandingkan dengan nilai $\mathrm{F}$ tabel yaitu $19,638>3,3541$.

Kesimpulan yang diperoleh Variabel bebas Analisis Fundamental ( $\left.\mathrm{X}_{1}\right)$ dan Analisis Teknikal $\left(\mathrm{X}_{2}\right)$ keduanya berpengaruh secara signifikan terhadap pengambilan keputusan (Y), karena mampunyai nilai $t_{\text {hitung }}$ yang lebih besar dibandingkan dengan nilai $t_{\text {tabel }}$, dari kedua Variabel tersebut Variabel Analisis Fundamental $\left(\mathrm{X}_{1}\right)$ berpengaruh paling dominan terhadap pengambilan keputusan (Y). secara menyeluruh dan bentuk tolak pada permasalahan yang di hadapi, maka saran yang dapat di berikan yaitu Diharapkan para trader forex harus berhati-hati dalam pengambilan keputusan dan untuk melakukan trading forex sangat diperlukan analisis fundamental atau teknikal sehingga resiko kerugian yang ditimbulkan dapat di minimalisir.

\section{KESIMPULAN DAN SARAN Kesimpulan}

Adapun kesimpulannya adalah sebagai berikut :

Dari hasil penelitian dapat diperoleh kesimpulan bahwa dari perhitungan anlisis regresi linier berganda dengan hasil koefisien $\mathrm{Y}=2,686+0,341 \quad \mathrm{X}_{1}+0,155 \mathrm{X}_{2}$ Hal ini dapat memberikan implikasi bahwa kedua variabel bebas ((Analisis Fundamental) $\mathrm{X}_{1}$ dan (Analisis Teknikal) $\mathrm{X}_{2}$ ) pada Trading Forex mempengarui variabel terikat yaitu pengambilan keputusan (Y). Secara simultan variabel bebas Analisis Fundamental $\left(\mathrm{X}_{1}\right)$ dan Analisis Teknikal $\left(\mathrm{X}_{2}\right)$ berpengaruh secara signifikan terhadap pengambilan keputusan (Y). Hal ini dibuktikan dengan besarnya nilai $\mathrm{F}_{\text {hitung }}$ dibandingkan dengan nilai $F$ tabel yaitu $19,638>3,3541$. Secara parsial variabel bebas Analisis Fundamental $\left(\mathrm{X}_{1}\right)$ berpengaruh secara signifikan terhadap pengambilan keputusan (Y) karena mampunyai nilai $t_{\text {hitung }}$ yang lebih besar dibandingkan 
dengan nilai $\mathrm{t}_{\text {tabel }}$ yaitu $5,345>2,052$. Sedangakan Analisis Teknikal $\left(\mathrm{X}_{2}\right)$ juga berpengaruh signifikan terhadap pengambilan keputusan (Y) karena nilai $t_{\text {hitung }}$ lebih besar dibandingkan dengan nilai $t_{\text {tabel }}$ yaitu 3,488 $>2,052$. Dengan ini variabel bebas Analisis Fundamental $\left(\mathrm{X}_{1}\right)$ dilihat dari perhitungan analisis regresi linier berganda $b_{1}=0,341 X_{1}$ dan Uji $t_{\text {hitung }}$ $\mathrm{X}_{1}=5,345$ maka $\left(\mathrm{X}_{1}\right)$ Analisis Fundamental lebih berpengaruh signifikan terhadap pengambilan keputusan (Y).

\section{SARAN}

Dengan melihat Fxindo Regional Lamongan secara menyeluruh dan bentuk tolak pada permasalahan yang di hadapi, maka saran yang dapat di berikan sebagai berikut pendukung pemecahan masalah yaitu Diharapkan para trader forex harus berhati-hati dan diperlukan analisis fundamental dann teknikal dalam menganalisis pergerakan harga untuk lebih baik dalam pengambilan keputusan.Untuk melakukan trading forex sangat diperlukan analisis fundamental atau teknikal dan harus mengetahui manajemen resiko sehingga resiko kerugian yang ditimbulkan dapat di minimalisir. Sebaiknya diadakan pelatihan trading forex secara rutin bagi para trader di FXindo agar kualitas pengambilan keputusan yang diambil dapat ditingkatkan.

\section{DAFTAR PUSTAKA}

Ihyaul Ulum MD,2008 akuntasi sektor publik, malang: uum press.

Deddi Nordiawan, Iswahyudi Sondi putra, Maulidah Rohmawati,2007. Akuntasi pemerintahan: Salemba Empat.

Abdul hafiz Tanjung,S.E.,M.Si.,Ak.2009. Akuntasi pemerintahan Daerah Konsep dan Aplikasi : Alfabeta Bandung.

Prof. Dr. Sugiyono.2007. Metode Penelitian kuantitatif kualitatif dan $R \& D$ : Alfabeta bandung.
Dikutip dari internet : http://ainiarie2012.blogspot.com/2013 102/belanja-daerah-proyeksi-dan.html

Prof. Dr. Abdul Halim, M.b.A.,Akt.,Muhammad Syam Kusufi, S.E. 2002. Akuntasi Keuangan Daerah : Salemba Empat.

Deddi Nordiawan,Ayuningtyas Hertianti,2010 Akuntasi Sektor Publik edisi 2 : Salemba Emapt

Prof. Dr. Suharsimi Arikunto,2002, Prosedur penelitian suatu pendekatan praktek: Rineka cipta.

Kompilasi peraturan pemerintah dalam Negeri Nomer 13 Tahun 2006 dengan Peraturan Pemerintah Dalam Negeri Nomor 59 Tahun 2007 Tentang Pendoman Pengelolaan Keuangan daerah.

Peraturan pemerintah Nomor 58 tahun 2005 tentang pengelolah keuangan Daerah UU Nomor 17 Tahun 2003 tentang Organisasi dan tata Kerja Dinas Daerah Kabupaten Lamongan 